\title{
Effect of molecular weight on hypolipidemic and hypoglycemic activities of fermented Auriculaia auricula supernatant
}

\author{
Yi-Hong $\mathrm{BAO}^{1 *}$, Kai-Feng SUN ${ }^{1}$ (D), Yang $\mathrm{GUO}^{1}$
}

\begin{abstract}
Auriculaia auricula is considered as species of $\mathrm{Mu} \mathrm{Er}$ in Chinese medicine and today are used interchangeably. A. auricula polysaccharides have been shown anti-cholesterol and anti-hyperglycemia. The aim of this research was to investigate the hypolipidemic and anti-hyperglycemic effects of extracts from different molecular weight fragments of $A$. auricula fermentation supernatant (AAFS). A. auricula was through mixed fermentation by Saccharomyces cerevisiae and Bifidobacterium. The results shown that with the molecular weight of AAFS increases, the ability to lower blood lipids and blood glucose gradually increases. In the lowering blood lipids, the AAFS of above $300 \mathrm{kDa}$ has the strongest sodium bovine cholate binding capacity and sodium taurocholate binding capacity. The AAFS of 100-300 kDa has the strongest sodium glycocholateas binding capacity. In the lowering blood glucose, the AAFS of 100-300 kDa has the strongest inhibition of a-amylase and $\alpha$-glucosidase activity. The AAFS of above $300 \mathrm{kDa}$ has the highest index of the glucose dialysis retardation at $30 \mathrm{~min}$, and $60 \mathrm{~min}$. The AAFS of 100-300 kDa has the highest index of the glucose dialysis retardation at $90 \mathrm{~min}$. The study shows that the ability of hypolipidemic and anti-hyperglycemic of AAFS can change with molecular weight, and the contents of substance has changed.
\end{abstract}

Keywords: Auriculaia auricula; fermentation; hyperglycemia; hyperlipidemia.

Pratical Application: Development of A. auricula functional food.

\section{Introduction}

Hyperglycemia and hyperlipidemia as a result of an imbalance between peripheral insulin sensitivity and peripheral insulin sensitivity in internal and organization are a group of prevalent disease symptom which is easy to lead to diabetes (Reilly \& Rader, 2003). Found in study that there is a obviously relationship between diabetes and lipid prole abnormalities (Roşu et al., 2000). The standard of HDL cholesterol and increase of LDL cholesterol have relationship with high blood glucose levels and this is a reasion of increasing risk of cardiovascular disease. The hyperlipidemia is a pivotal factor of atherosclerosis, thrombus and many lipid abnormal symptom such as obesity, coronary heart disease and brain infarction and peripheral vascular disease. According to reports that high levels of cholesterol and blood lipid reduces antioxidative enzyme activities (Revenko et al., 1991). Therefore, it is critical for modern person to contral their blood sugar and lipid levels in order to decreasing the risk of diabetes and cardiovascular diseases (Sudasinghe \& Peiris, 2018). The effective method for reducing high blood sugar involves the supply of insulin or other drugs with decreasing blood sugar function in combine with recommendations for diet regulation and exercise training (Caprio \& Fonseca, 2014).

A. auricula (Family: Auriculaia; common name: Jew's ear, wood ear, jelly ear) is a species of edible fungus found all over the world. As a result of their physiologically beneficial bioactive compounds, A. auricula has been taken to be a precious natural resources because of its valuable edible value and medicinal value. Such as antioxidant (Lu et al., 2018a), anti-aging (Zhang et al., 2016), hypolipidemic (Reza et al., 2015), hypoglycemic (Lu et al., 2018b), resist fatigue, anticancer (Huang \& Nie, 2015), anti-inflammatory (Dereje et al., 2011), hepatoprotective (Tong et al., 2015) and immunoregulation (Zeng et al., 1994) effects.

Saccharomyces cerevisiae and Bifidobacterium were proved to be symbiotic. According to our previous research on the function of A. auricula about hyperglycemia and hyperlipidemia, the A. auricula was mixed fermentation by Saccharomyces cerevisiae and Bifidobacterium got better bile salts binding capacity, cholesterol adsorption capacity and sodium cholate binding capacity in vitro. Several authors stated the one source of probioactive is a compound that appears as a result of the modification of the foodmatrix itself by the probiotic culture. Probiotics could produce bioactives that would improve the nutritive and functional value (Champagne et al., 2018). Probiotic strains of Lactobacillus and Saccharomyces have an extensive safety record for their consumption by the healthy population, and the Saccharomyces have been considered as one of the microorganisms which present probiotic potential (Cassanego et al., 2018). With the fermentation of Saccharomyces cerevisiae advancing, some substances in the medium will also change in content, such as reducing suger (Sun et al., 2019). The present study was designed to inspect the difference about different molecular weight fragment of the liquid of A. auricula after fermentation on reducing hyperglycemia and hyperlipidemia. Moreover, the difference about substance content in different molecular weight fragment of the liquid of $A$. auricula after fermentation compared with $A$. auricula was also analysed. 


\section{Materials and methods}

\subsection{Materials}

The materials of $A$. auricula were provided from Jiagedaqi Forestry Bureau, Daxinganling District, Heilongjiang Province. The material was authenticated at Institute of Microbiology, Heilongjiang Academy of Sciences. The $\alpha$-amylase and $\alpha$-glucosidase was provided by Shanghai Yuanye Biological Technology Co., Ltd. The enzyme activity of $\alpha$-amylase and $\alpha$-glucosidase was analysed by pre-test. The standard cholate samples, including sodium cholate, sodium taurocholate and sodium glycocholateas was provided Beijing Biotopped Science \& Technology Co., Ltd.

\subsection{Preparation of different molecular weight A. auricula fermentation extracts}

1 grams of $A$. auricula power which sifted through a 200 mesh screen was mixed with $100 \mathrm{~mL}$ distilled water. The mixture was fermented by Bifidobacterium and Saccharomyces cerevisiae at $30^{\circ} \mathrm{C}$ for $60 \mathrm{~h}$ to obtain the $A$. auricula fermentation broth. The different molecular weight $A$. auricula fermentation extracts $(0-10 \mathrm{kDa}$, $10-30 \mathrm{kDa}, 30-50 \mathrm{kDa}, 50-100 \mathrm{kDa}, 100-300 \mathrm{kDa},>300 \mathrm{kDa})$ was getted by different molecular weight ultrafiltration centrifuge tubes, 4000rpm, 10min.

\subsection{Analyze testing the inhibition of $\alpha$-amylase activity}

The dry matter of AAFS was dissolved in phosphate buffer ( $\mathrm{pH}$ 6.8) and confected into $0.4 \mathrm{mg} / \mathrm{mL}$ concentrations. The reaction system including the AAFS solutions $(0.04 \mathrm{~mL}$, $0.4 \mathrm{mg} / \mathrm{mL})$ and $\alpha$-amylase $(0.2 \mathrm{~mL}, 6 \mathrm{U} / \mathrm{mL})$ was activated by the addition of the starch solution $(0.1 \mathrm{~mL}, 1 \%, \mathrm{w} / \mathrm{v})$ and activated for 10 minutes under the condition of $37^{\circ} \mathrm{C}$ water bath. Until the reaction was stoped by adding the agentia of DNS. After the reaction system was reacted in boiling water for 5 minutes and diluted with $10 \mathrm{~mL}$ distilled water, the absorbance was measured at $540 \mathrm{~nm}$ (Luyen et al., 2018), and the $\alpha$-amylase inhibition rate was calculated by following formula:

$\alpha-\operatorname{amylase}$ inhibition $(\%)=\frac{\mathrm{A}_{0}-\left(\mathrm{A}_{1}-\mathrm{A}_{2}\right)}{\mathrm{A}_{0}} \times 100 \%$

$A_{0}$ was the absorbance of the phosphate buffer; $A_{1}$ was the absorbance of the reaction system including enzymatic reaction system and sample; and $\mathrm{A}_{2}$ was the absorbance of the $\alpha$-amylase enzymatic reaction system.

\subsection{Analyze testing the inhibition of $\alpha$-glucosidase activity}

The dry matter of AAFS was dissolved in phosphate buffer ( $\mathrm{pH}$ 6.8) and confected into $0.4 \mathrm{mg} / \mathrm{mL}$ concentrations. The $a$-glucosidase $(0.05 \mathrm{~mL}, 7 \mathrm{U} / \mathrm{mL})$ was blended with the AAFS solutions $(0.04 \mathrm{~mL}, 0.4 \mathrm{mg} / \mathrm{mL})$. The mixture was activited 10 minutes under the condition of $37^{\circ} \mathrm{C}$ water bath. Then reacted by adding PNPG $(0.05 \mathrm{~mL}, 10 \mathrm{mg} / \mathrm{mL})$ and the reaction system was reacted at 15 minutes under the condition of $37^{\circ} \mathrm{C}$ water bath (Ilias et al., 2018). And the reaction was ended by adding the reagent of sodium carbonate $(0.01 \mathrm{~mL}, 1 \mathrm{~mol} / \mathrm{L})$. The dialysate's absorbance was measured at $405 \mathrm{~nm}$, and the a-glucosidase inhibition rate was calculated by following formula: $\alpha-$ glucosidase inhibition $(\%)=\frac{\mathrm{A}_{0}-\left(\mathrm{A}_{1}-\mathrm{A}_{2}\right)}{\mathrm{A}_{0}} \times 100 \%$

$A_{0}$ was the absorbance of the phosphate buffer; $A_{1}$ was the absorbance of the reaction system including enzymatic reaction system and sample; and $\mathrm{A}_{2}$ was the absorbance of the a-glucosidase enzymatic reaction system.

\subsection{Analyze testing the glucose dialysis retardation index}

The dry matter of AAFS was dissolved in phosphate buffer ( $\mathrm{pH}$ 6.8) and confected into $0.4 \mathrm{mg} / \mathrm{mL}$ concentrations. The glucose solutions $(10 \mathrm{~mL}, 0.1 \mathrm{~mol} / \mathrm{L})$ was premixed with the AAFS solutions ( $1 \mathrm{~mL}, 0.4 \mathrm{mg} / \mathrm{mL}$ ) and shaked at $37{ }^{\circ} \mathrm{C}$, $120 \mathrm{rpm}$ for $1 \mathrm{~h}$. Then the mixture was put into dialysate bag $(10 \mathrm{~cm}, 7000 \mathrm{D})$ which was put into $150 \mathrm{~mL}$ deionized water and shaked at $37^{\circ} \mathrm{C}, 120 \mathrm{rpm}$ for $1 \mathrm{~h}$. The absorbance was measured at $490 \mathrm{~nm}$ by phenol sulfuric acid assay at 30min, 60min and 90min (Fuentes-Alventosa et al., 2009). The index of glucose dialysis retardation was calculated by following formula:

Glucose dialysis retardation index $(\%)=\left(1-\frac{\mathrm{A}_{1}}{\mathrm{~A}_{2}}\right) \times 100 \%$

$A_{1}$ was the glucose dialysis of the sample group, $A_{2}$ was the glucose dialysis of the experimental group.

\subsection{Bile salts binding capacity (BBC)}

The sodium bovine cholate, sodium taurocholate and sodium glycocholate wa used as detection agents to detect the in vitro bile salt binding capacity of AAFS in a simulated human bile system (Gomez et al., 2018). The calculation of BBC as following:

$\operatorname{BBC}(\%)=\frac{\left(\mathrm{C}_{1}-\mathrm{C}_{2}\right)}{\mathrm{C}_{1}} \times 100 \%$

$\mathrm{C}_{1}$ was the concentration of the original bile salt in the reaction solution; $\mathrm{C}_{2}$ was the concentration of the bile salt remaining in the reaction solution.

\subsection{Comparison of total sugar content}

The dry matter of AAFS and A. auricula supernatant (AAS) was dissolved in distilled water and confected into $0.4 \mathrm{mg} / \mathrm{mL}$ concentrations. The solution of AAFS and AAS $(1 \mathrm{~mL}, 0.4 \mathrm{mg} / \mathrm{mL})$ was placed in $10 \mathrm{~mL}$ test tubes, $1 \mathrm{~mL}$ of $5 \%$ phenol and $6 \mathrm{~mL}$ $\mathrm{H}_{2} \mathrm{SO}_{4}$ was added and shaken and mixed quickly. Then the mixture was placed at room temperature for $30 \mathrm{~min}$ and the absorbance was measured at $490 \mathrm{~nm}$. The total sugar content was calculated by standard curve.

\subsection{Comparison of reducing sugar content}

The dry matter of AAFS and AAS was dissolved in distilled water and confected into $0.4 \mathrm{mg} / \mathrm{mL}$ concentrations. The solution of AAFS and AAS $(2 \mathrm{~mL}, 0.4 \mathrm{mg} / \mathrm{mL})$ was mixed with DNS reagents and reacted in boiling water for $5 \mathrm{~min}$ (Isarawut et al., 2018). The reaction system was cooled in ice water and then diluted to a volume of $25 \mathrm{~mL}$. The absorbance was measured 
at $560 \mathrm{~nm}$ and the reducing sugar content was calculated by standard curve.

\subsection{Comparison of polysaccharide content}

The dry matter of AAFS and AAS was dissolved in distilled water and confected into $0.4 \mathrm{mg} / \mathrm{mL}$ concentrations. The solution of AAFS and AAS $(1 \mathrm{~mL}, 0.4 \mathrm{mg} / \mathrm{mL})$ was added into $10 \mathrm{~mL}$ absolute ethyl alcohol and placed into $50 \mathrm{~mL}$ centrifugal tubes. And then the mixture was centrifuged at $4000 \mathrm{r} / \mathrm{min}$ for $10 \mathrm{~min}$. Then the supernatant was abandoned and the precipitates were washed by absolute ethyl alcohol for 3 times. It was dissolve to $50 \mathrm{~mL}$ by distilled water and then take $2 \mathrm{~mL}$ liquid diluted to a volume of $10 \mathrm{~mL}$. The polysaccharide content was determined by phenol-sulfuric acid, like 2.4.1.

\subsection{Comparison of polyphenol content}

The dry matter of AAFS and AAS was dissolved in distilled water and confected into $0.4 \mathrm{mg} / \mathrm{mL}$ concentrations. The solution of AAFS and AAS $(2 \mathrm{~mL}, 0.4 \mathrm{mg} / \mathrm{mL})$ was premixed with $2 \mathrm{~mL}$ Foline-phenol and $\mathrm{Na}_{2} \mathrm{CO}_{3}$ solution $(5 \mathrm{~mL}, 20 \% \mathrm{w} / \mathrm{v})$ and then diluted to a volume of $50 \mathrm{~mL}$. The reaction was reacted at $50{ }^{\circ} \mathrm{C}$ for $45 \mathrm{~min}$ and the absorbance was measured at $765 \mathrm{~nm}$ (Sun et al., 2014).

\subsection{Comparison of flavonoids content}

The dry matter of AAFS and AAS was dissolved in distilled water and confected into $0.067 \mathrm{mg} / \mathrm{mL}$ concentrations. The solution of AAFS and AAS $(1 \mathrm{~mL}, 0.067 \mathrm{mg} / \mathrm{mL})$ was premixed with $\mathrm{Na}_{2} \mathrm{NO}_{2}$ $(1 \mathrm{~mL}, 5 \% \mathrm{w} / \mathrm{v})$ for $6 \mathrm{~min}$ and added $\mathrm{Al}\left(\mathrm{NO}_{3}\right)_{3}(1 \mathrm{~mL}, 10 \% \mathrm{w} / \mathrm{v})^{2}$ for $6 \mathrm{~min}$ and then mixed in $\mathrm{NaOH}(10 \mathrm{~mL}, 10 \% \mathrm{w} / \mathrm{v})$ for $15 \mathrm{~min}$. The absorbance was measured at $510 \mathrm{~nm}$ and the flavonoids content was calculated by standard curve.

\subsection{Statistical analysis}

The data analysis was performed by one-way ANOVA of SPSS 20.0 software. And P-values $<0.05$ was considered to be statistically significant.

\section{Results and discussion}

\subsection{Inhibitory effects of different molecular weight AAFS on $\alpha$-amylase}

As shown in Figure 1, the different molecular weight AAFS was confirmed that have a certain degree of inhibitory effects of $\alpha$-amylase effect. It was shown that AAFS of have the strongest inhibition of $\alpha$-amylase activity that can reach $66.74 \%$, and there is no significant difference between $100-300 \mathrm{kDa}$ and above $300 \mathrm{kDa}(\mathrm{p}>0.05)$. A-amylase is one of the most important substances secreted in the pancreas and salivary glands that plays a momentous role in gastro-intestinal digestion. The polysaccharides are the main component of A. auricula. Several researches have shown that the biological function and characteristics of polysaccharides are concerned with their structure and composition (Ma et al., 2013), especially the molecular weight plays a major part (Liu et al., 2018). Therefore, the inhibition of $a$-amylase by different molecular weight AAFS may be associated with differences among polysaccharides of different molecular weight. Some research reported that the polysaccharides' molecular chain should be within a reasonably scope to maintain its biological activity and function (Calazans et al., 2000). The AAFS of $100-300 \mathrm{kDa}$ and above $300 \mathrm{kDa}$ can inhibit more effectively the activity of $\alpha$-amylase.

\subsection{Inhibitory effects of different molecular weight AAFS on $\alpha$-glucosidase}

It was shown in Figure 2 that AAFS of 100-300 kDa have the strongest inhibition on the activity of $\alpha$-glucosidase that can reach $79.64 \%$ and there is no significant difference between $100-300 \mathrm{kDa}$, $50-100 \mathrm{kDa}$ and above $300 \mathrm{kDa}(\mathrm{p}>0.05)$. A-glucosidase is one of

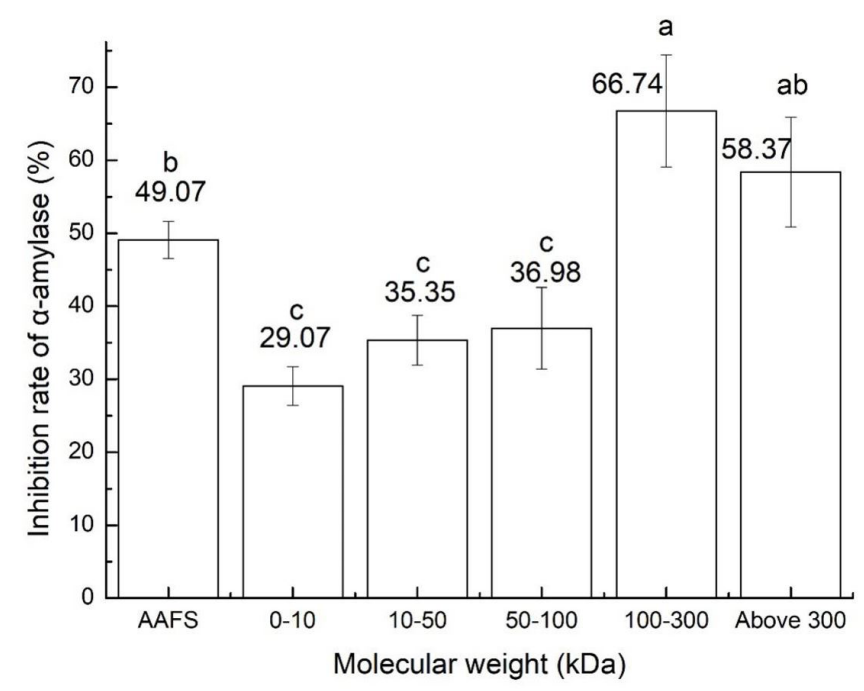

Figure 1. The inhibitory effects of different molecular weight AAFS on a-amylase activity. The results were statistically compared by Duncan's multiple-range test. Means with different letters in the figure indicate significant differences $(\mathrm{P}<0.05)$.

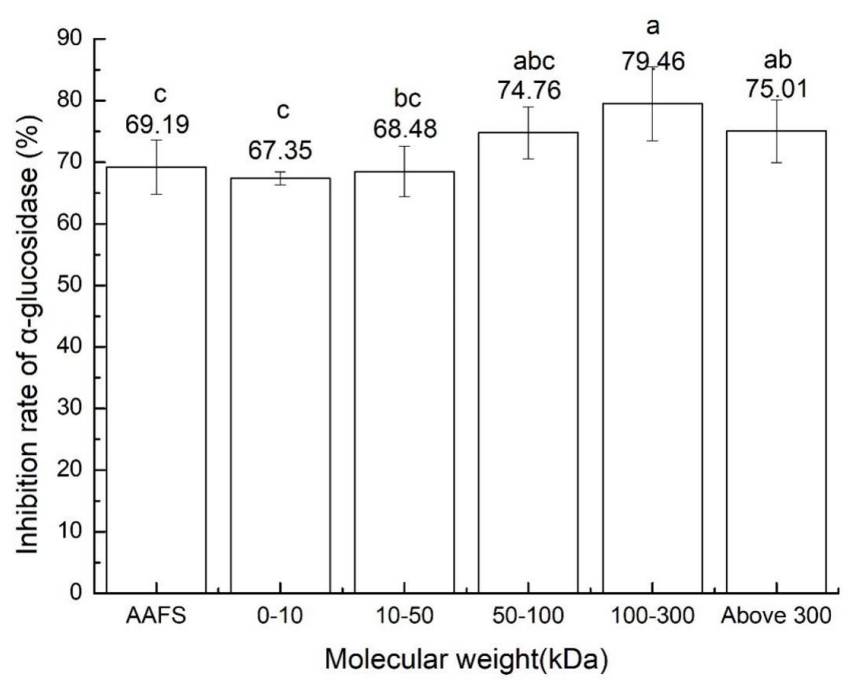

Figure 2. The inhibitory effects of different molecular weight AAFS on $\alpha$-glucosidase activity. The results were statistically compared by Duncan's multiple-range test. Means with different letters in the figure indicate significant differences $(\mathrm{P}<0.05)$. 
the representative enzyme in postprandial carbohydrate digestive enzymes, which helps to digest postprandial carbohydrates in the body (Lavelli et al., 2016). Minbae et al. (2016) show that the extraction from edible fungus can as the $\alpha$-glucosidase inhibitor has an antiglycemic effect. And the inhibitor was examed an antiglycemic effect in diabetic rats. The greater molecular weight AAFS can decrease the absorption of carbohydrates by inhibiting activity of $\alpha$-glucosidase to lower the postprandial blood glucose levels effectively (Ghani, 2015).

\subsection{The index of glucose dialysis retardation of different molecular weight AAFS}

The effects of AAFS on the index of glucose dialysis retardation are displayed in Figure 3. As shown, the AAFS and above $300 \mathrm{kDa}$ has the highest index of glucose dialysis retardation at $30 \mathrm{~min}, 60 \mathrm{~min}$ and the index of glucose dialysis retardation can attain respectively $30.34 \%, 32.30 \%$. In the index of glucose dialysis retardation of different molecular weight AAFS between these two time periods, there is no significant difference between above $300 \mathrm{kDa}$ and $100-300 \mathrm{kDa}(\mathrm{p}>0.05)$. The AAFS of $100-300 \mathrm{kDa}$ has the highest index of glucose dialysis retardation at $90 \mathrm{~min}$ and the index of glucose dialysis retardation can attain $36.94 \%$. There is no significant difference between above $300 \mathrm{kDa}$ and $100-300 \mathrm{kDa}(\mathrm{p}>0.05)$. A previous research showed that the delayed index of glucose diffusion and absorption is influenced by viscosity of the digesta in intestinal tract (Edwards et al., 1987) and that viscous polysaccharides may induce the intestinal absorb of nutrients by augmenting the apparent thickness of the unstirred water layer (Fan et al., 2015). This discrepancy of different molecular weight AAFS in the aspect of glucose dialysis retardation index was due to differences in physical characteristics, such as water holding capacity, gelling property, and the viscosity of the solution. Based on these results, larger molecular weight polysaccharide

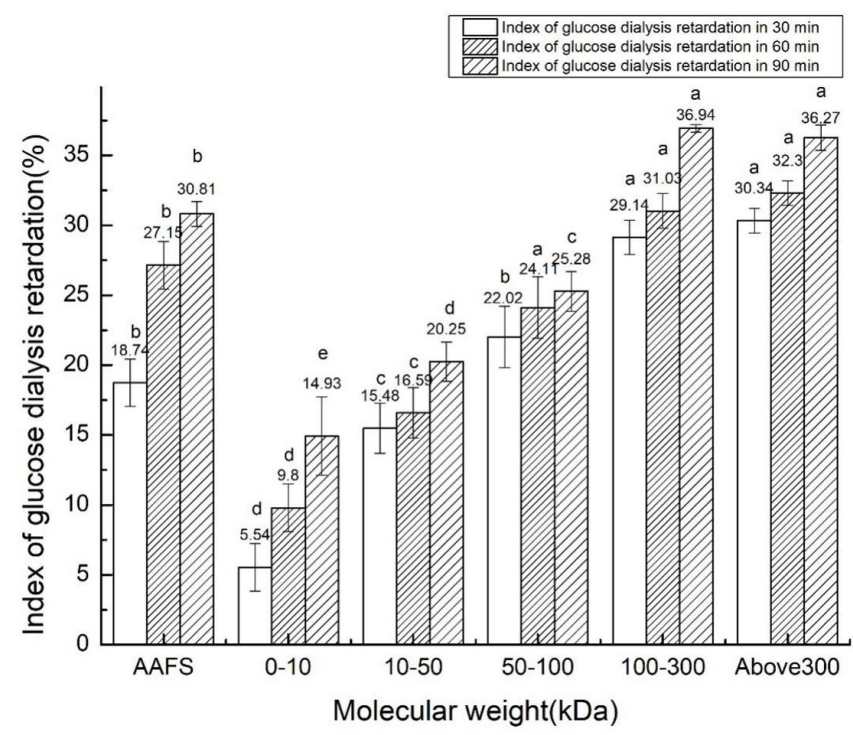

Figure 3. The index of glucose dialysis retardation of different molecular weight AAFS. The results were statistically compared by Duncan's multiple-range test. Means with different letters in the figure indicate significant differences $(\mathrm{P}<0.05)$. fractions, particularly $100-300 \mathrm{kDa}$ and above $300 \mathrm{kDa}$, are likely to dissolve and create network-link in solvent, thus delaying the diffusion rate of glucose and the absorption of glucose in the gastrointestinal tract is prevented (Oh \& Yoon, 2018).

\subsection{Bile salts binding capacity (BBC)}

The research results of $\mathrm{BBC}$ are displayed in Figure 4. The AAFS of above $300 \mathrm{kDa}$ has the strongest sodium bovine cholate binding capacity and sodium taurocholate binding capacity that can reach $68.65 \%$, and $88.58 \%$. There is no significant difference between above $300 \mathrm{kDa}$ and $100-300 \mathrm{kDa}(\mathrm{p}>0.05)$. The AAFS of $100-300 \mathrm{kDa}$ has the strongest sodium glycocholateas binding capacity that can reach $96.47 \%$ and there is no significant difference between above $300 \mathrm{kDa}$ and $100-300 \mathrm{kDa}(\mathrm{p}>0.05)$. The AAFS with different molecular weight can bind bile salts in the human intestine. Thus inhibiting their reuptake by the intestinal ileum cells and reducing the production of fat. As the molecular weight increases, the index of $\mathrm{BBC}$ continues to rise. This may be due to the high molecular weight of AAFS in the composition and structure of polysaccharides with stronger bile salts binding capacity (Vinti Goel Ph, 1998). Susanne Nauman's research show that the in vitro model examed desplays the effect of adsorption and viscosity on bile acid reabsorption reduction. It was affirmed by the relevance of release dynamics with adsorption and viscosity properties. Accordingly, in according to the in vivo experiment findings, the viscosity effect has a decisive effect on the release rate of high fiber barley products (Naumann et al., 2018).

\subsection{Total sugar content}

The results were statistically compared by Duncan's multiple-range test. Means with different letters in the table indicate significant differences $(\mathrm{P}<0.05)$.

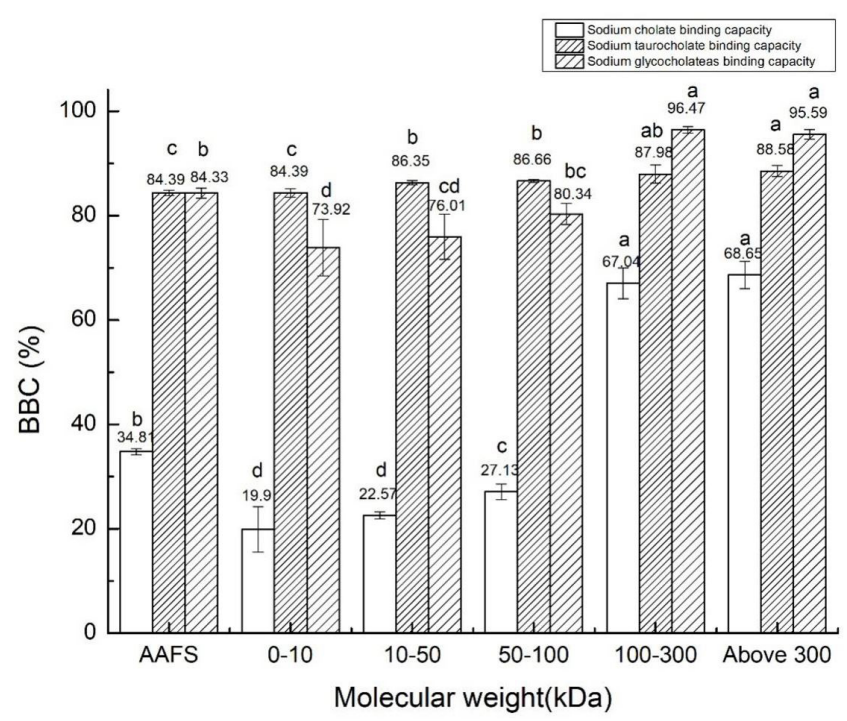

Figure 4. The binding capacity of the different molecular weight AAFS on bile salts. The results were statistically compared by Duncan's multiple-range test. Means with different letters in the figure indicate significant differences $(\mathrm{P}<0.05)$. 
As shown in Table 1, with the fermentation of Saccharomyces cerevisiae and Bifidobacterium that the content of substances in the A. auricula has also changed slightly. Compared with A. auricula before fermentation, the total sugar content of AAS increased significantly after fermentation and the total sugar content of the fermentation broth of different molecular weight fractions after fermentation was increased compared to the respective molecular weight fragments before fermentation. The AAFS of above $300 \mathrm{kDa}$ has the highest total sugar content and can reach $1297.43 \mathrm{mg} / \mathrm{L}$. The total sugar content of AAFS at above $300 \mathrm{kDa}$ was significantly different from the total sugar content of other molecular weight AAFS ( $p<0.05)$. It is clear from Table. 1 that the total sugar was increased during fermentation. In previous research, the total sugar content of $A$. auricula was attested that had increased after fermentation. This means that the substance content of the medium based on A. auricula was changed by the microorganism's effect.

\subsection{Reducing sugar content}

As shown in Table 2, Compared with AAFS, the reducing sugar content of AAS has no changed significantly. But the AAS of $100-300 \mathrm{kDa}$ has the highest reducing sugar content and can reach $4.78 \mathrm{mg} / \mathrm{L}$. The reducing sugar content of AAS at 100-300 kDa was significantly different from the reducing sugar content of other molecular weight AAS $(\mathrm{p}<0.05)$. Aplin et al. (2019) showed that Saccharomyces yeasts consumed the reducing sugar in wines, this is similar to the results of our study.

\subsection{Polysaccharide content}

As shown in Table 3, the polysaccharide content of AAS increased significantly after fermentation and the polysaccharide content of 100-300 kDa was increased more compared to the respective molecular weight fragments before fermentation. The AAFS of $100-300 \mathrm{kDa}$ has the highest polysaccharide content and can reach $823.09 \mathrm{mg} / \mathrm{L}$. The polysaccharide content of AAFS at $100-300 \mathrm{kDa}$ was significantly different from the polysaccharide content of other molecular weight AAFS ( $\mathrm{p}<0.05)$. Some researches by González-Royo et al. (2017) reported that the yeasts can increase the concentration of polysaccharides in red wine. Because the yeasts can releas polysaccharides and oligosaccharides. The increase of polysaccharides concentration detected in red wine supplemented with Optired was mainly due to the intermediate molecular weight fraction $(40-144 \mathrm{kDa})$ and low molecular weight fraction $(5-40 \mathrm{kDa})$. The previous study by Zhu et al. (2016) found that polysaccharide isolated from Ganoderma atrum (PSG-1) exerted hypoglycemic and hypolipidemic effects through inhibiting expression of Bax and improving the expression of $\mathrm{Bcl}-2$ protein in pancreatic tissues of type 2 diabetic rats.

\subsection{Polyphenol content}

As shown in Table 4, as the molecular weight increases, the polyphenol content gradually reduces. The AAS of $0-10 \mathrm{kDa}$ has the highest polyphenol content and can reach $3.85 \mathrm{mg} / \mathrm{mL}$. The polyphenol content of AAS at 0-10 kDa was significantly

Table 1. The total sugar content of the different molecular weight AAFS and AAS.

\begin{tabular}{lcccccc}
\hline \multicolumn{7}{c}{ Total sugar(mg/L) } \\
\hline Molecular weight $(\mathrm{kDa})$ & AAS/AAFS & $0-10$ & $10-50$ & $50-100$ & $100-300$ & $>300$ \\
\hline Before fermentation & $1090.33 \pm 45.06^{\mathrm{b}}$ & $982.03 \pm 46.04^{\mathrm{c}}$ & $1074.23 \pm 34.51^{\mathrm{b}}$ & $1099.11 \pm 61.52^{\mathrm{b}}$ & $1122.53 \pm 16.46^{\mathrm{b}}$ & $1271.82 \pm 10.98^{\mathrm{a}}$ \\
After fermentation & $1164.97 \pm 13.41^{\mathrm{b}}$ & $1001.42 \pm 50.84^{\mathrm{c}}$ & $1170.10 \pm 18.41^{\mathrm{b}}$ & $1163.51 \pm 51.69^{\mathrm{b}}$ & $1206.69 \pm 22.77^{\mathrm{b}}$ & $1297.43 \pm 8.94^{\mathrm{a}}$ \\
\hline
\end{tabular}

Table 2. The reducing sugar content of the different molecular weight AAFS and AAS.

\begin{tabular}{lcccccc}
\hline \multicolumn{7}{c}{ Reducing sugar content $(\mathrm{mg} / \mathrm{L})$} \\
\hline Molecular weight $(\mathrm{kDa})$ & AAS/AAFS & $0-10$ & $10-50$ & $50-100$ & $100-300$ & $>300$ \\
\hline Before fermentation & $3.68 \pm 0.29^{\mathrm{b}}$ & $3.71 \pm 0.18^{\mathrm{b}}$ & $3.20 \pm 0.13^{\mathrm{b}}$ & $3.23 \pm 0.21^{\mathrm{b}}$ & $4.78 \pm 16.5^{\mathrm{a}}$ & $3.28 \pm 0.71^{\mathrm{b}}$ \\
After fermentation & $3.40 \pm 0.27^{\mathrm{b}}$ & $3.37 \pm 0.27^{\mathrm{b}}$ & $3.11 \pm 0.27^{\mathrm{bc}}$ & $2.58 \pm 0.08^{\mathrm{d}}$ & $4.19 \pm 0.39^{\mathrm{a}}$ & $2.60 \pm 0.35^{\mathrm{cd}}$ \\
\hline
\end{tabular}

The results were statistically compared by Duncan's multiple-range test. Means with different letters in the table indicate significant differences $(\mathrm{P}<0.05)$.

Table 3. The polysaccharide content of the different molecular weight AAFS and AAS.

\begin{tabular}{lcccccc}
\hline \multicolumn{7}{c}{ Polysaccharide content $(\mathrm{mg} / \mathrm{L})$} \\
\hline Molecular weight $(\mathrm{kDa})$ & AAS/AAFS & $0-10$ & $10-50$ & $50-100$ & $100-300$ & $>300$ \\
\hline Before fermentation & $613.06 \pm 18.75^{\mathrm{b}}$ & $489.39 \pm 43.98^{\mathrm{c}}$ & $484.10 \pm 42.19^{\mathrm{c}}$ & $621.11 \pm 67.50^{\mathrm{b}}$ & $670.87 \pm 77.87^{\mathrm{ab}}$ & $749.18 \pm 15.83^{\mathrm{a}}$ \\
After fermentation & $658.43 \pm 10.38^{\mathrm{c}}$ & $599.16 \pm 17.61^{\mathrm{cd}}$ & $620.38 \pm 6.71^{\mathrm{cd}}$ & $570.62 \pm 53.16^{\mathrm{d}}$ & $823.09 \pm 51.86^{\mathrm{a}}$ & $754.30 \pm 40.50^{\mathrm{b}}$ \\
\hline
\end{tabular}

The results were statistically compared by Duncan's multiple-range test. Means with different letters in the table indicate significant differences $(\mathrm{P}<0.05)$.

Table 4. The polyphenol content of the different molecular weight AAFS and AAS.

\begin{tabular}{lcccccc}
\hline \multicolumn{7}{c}{ Polyphenol content $(\mathrm{mg} / \mathrm{mL})$} \\
\hline Molecular weight $(\mathrm{kDa})$ & AAS/AAFS & $0-10$ & $10-50$ & $50-100$ & $100-300$ & $>300$ \\
\hline Before fermentation & $3.43 \pm 0.16^{\mathrm{ab}}$ & $3.85 \pm 0.09^{\mathrm{a}}$ & $3.40 \pm 0.43^{\mathrm{ab}}$ & $2.92 \pm 0.16^{\mathrm{b}}$ & $1.68 \pm 0.10^{\mathrm{c}}$ & $1.45 \pm 0.46^{\mathrm{c}}$ \\
After fermentation & $2.86 \pm 0.21^{\mathrm{ab}}$ & $3.48 \pm 0.59^{\mathrm{a}}$ & $2.69 \pm 0.15^{\mathrm{bc}}$ & $2.27 \pm 0.28^{\mathrm{bc}}$ & $2.05 \pm 0.49^{\mathrm{c}}$ & $1.36 \pm 0.14^{\mathrm{d}}$ \\
\hline
\end{tabular}

The results were statistically compared by Duncan's multiple-range test. Means with different letters in the table indicate significant differences (P <0.05). 
Table 5. The flavonoids content of the different molecular weight AAFS and AAS.

\begin{tabular}{lcccccc}
\hline \multicolumn{7}{c}{ Flavonoids content $(\mathrm{mg} / \mathrm{L})$} \\
\hline Molecular weight $(\mathrm{kDa})$ & AAS/AAFS & $0-10$ & $10-50$ & $50-100$ & $100-300$ & $>300$ \\
\hline Before fermentation & $131.36 \pm 1.75^{\mathrm{b}}$ & $183.26 \pm 10.09^{\mathrm{a}}$ & $136.03 \pm 2.02^{\mathrm{b}}$ & $110.96 \pm 5.62^{\mathrm{c}}$ & $88.22 \pm 11.25^{\mathrm{d}}$ & $73.06 \pm 6.62^{\mathrm{e}}$ \\
After fermentation & $172.88 \pm 5.34^{\mathrm{b}}$ & $218.36 \pm 15.87^{\mathrm{a}}$ & $177.54 \pm 27.49^{\mathrm{b}}$ & $144.31 \pm 17.49^{\mathrm{c}}$ & $130.31 \pm 17.49^{\mathrm{c}}$ & $128.56 \pm 3.03^{\mathrm{c}}$ \\
\hline
\end{tabular}

The results were statistically compared by Duncan's multiple-range test. Means with different letters in the table indicate significant differences $(\mathrm{P}<0.05)$.

different from the polyphenol content of other molecular weight AAFS $(\mathrm{p}<0.05)$ and AAS has higher polyphenol content than AAFS. Zieliński et al. (2019) showed that fermented material by L. plantarum caused increase in contents of total phenolic compounds compared to untreated raw material. Because the molecular weight of the total phenolic compounds is small, and it becomes less and less as the molecular weight increases.

\subsection{Flavonoids content}

As shown in Table 5, as the molecular weight increases, the flavonoids content gradually reduces. The AAFS of $0-10 \mathrm{kDa}$ has the highest flavonoids content and can reach $218.36 \mathrm{mg} / \mathrm{L}$. The flavonoid content of AAFS is higher than that of AAS. The flavonoids content of AAFS at $0-10 \mathrm{kDa}$ was significantly different from the flavonoids content of other molecular weight AAFS $(\mathrm{p}<0.05)$ and AAFS has higher flavonoids content than AAS. Adebo et al. (2018) showed that fermented samples obtained at $27^{\circ} \mathrm{C}$ for $24 \mathrm{~h}$ had significantly $(\mathrm{p}<0.05)$ higher flavonoids content values for these parameters. The molecular weight of the flavonoids content is small, so it becomes less and less as the molecular weight increases.

\section{Conclusions}

This study demonstrated that there are different function on hypolipidemic and hypoglycemic of different molecular weight AAFS. And the content of substances has changed compared with AAS. In the function of hypolipidemic and hypoglycemic, according to the experiment of the inhibition of $\alpha$-amylase activity and $\alpha$-glucosidase activity, the AAFS of $100-300 \mathrm{kDa}$ and above $300 \mathrm{kDa}$ have stronger functional activity. In the substance contents, the content of AAFS's total sugar, reducing sugar, polysaccharide, polyphenol and flavonoids has changed compared with AAS, and the content of substances are different with different molecular weight.

\section{Acknowledgements}

This study was supported by the '13th Five-Year Plan' National Key R\&D Initiative Project (Project No.2018YFD0401101), Northeast Forestry University Ph.D. Independent Innovation Fund Project (Project No. 2572017AA02).

\section{References}

Adebo, O. A., Njobeh, P. B., Adebiyi, J. A., \& Kayitesi, E. (2018). Coinfluence of fermentation time and temperature on physicochemical properties, bioactive components and microstructure of ting (a Southern African food) from whole grain sorghum. Food Bioscience, 25, 118-127. http://dx.doi.org/10.1016/j.fbio.2018.08.007.
Aplin, J. J., White, K. P., \& Edwards, C. G. (2019). Growth and metabolism of non-Saccharomyces yeasts isolated from Washington state vineyards in media and high sugar grape musts. Food Microbiology, 77, 158168. http://dx.doi.org/10.1016/j.fm.2018.09.004. PMid:30297046.

Calazans, G. M. T., Lima, R. C., França, F. P., \& Lopes, C. E. (2000). Molecular weight and antitumour activity of Zymomonas mobilis levans. International Journal of Biological Macromolecules, 27(4), 245-247. http://dx.doi.org/10.1016/S0141-8130(00)00125-2.

Caprio, G. R. A., \& Fonseca, V. A. (2014). Update on safety issues related to antihyperglycemic therapy. Diabetes Spectrum, 27(2), 97-100. http://dx.doi.org/10.2337/diaspect.27.2.92. PMid:26246765.

Cassanego, D., Richards, N., Valente, P., Mazutti, M., \& RamírezCastrillon, M. (2018). Identification by PCR and evaluation of probiotic potential in yeast strains found in kefir samples in the city of Santa Maria, RS, Brazil. Food Science and Technology, 38(1), 59-65. http://dx.doi.org/10.1590/1678-457X.13617.

Champagne, P. C., Cruz, A. G., \& Daga, M. (2018). Strategies to improve the functionality of probiotics in supplements and foods. Shipin Kexue, 22, 160-166. http://dx.doi.org/10.1016/j.cofs.2018.04.008

Dereje, D., Ahsanur, R. M., Seung-Jin, L., Woo-Sik, J., \& Seung-Chun, P. (2011). Anti-inflammatory Activity of Dichloromethane Extract of Auriculaia auricula-judae in RAW264.7 Cells. Toxicological Research,27(1), 11-14. http://dx.doi.org/10.5487/TR.2011.27.1.011. PMid:24278544.

Edwards, C. A., Blackburn, N. A., Craigen, L., Davison, P., Tomlin, J., Sugden, K., Johnson, I. T., \& Read, N. W. (1987). Viscosity of food gums determined in vitro related to their hypoglycemic actions. The American Journal of Clinical Nutrition, 46(1), 72-77. http://dx.doi. org/10.1093/ajcn/46.1.72. PMid:3604971.

Fan, T., Hu, J. G., Fu, L. D., \& Zhang, L. J. (2015). Optimization of enzymolysis-ultrasonic assisted extraction of polysaccharides from Momordica charabia L. by response surface methodology. Carbohydrate Polymers, 115(22), 701-706. http://dx.doi.org/10.1016/j. carbpol.2014.09.009. PMid:25439951.

Fuentes-Alventosa, J. M., Rodríguez-Gutiérrez, G., Jaramillo-Carmona, S., Espejo-Calvo, J. A., Rodríguez-Arcos, R., Fernández-Bolaños, J., Guillén-Bejarano, R., \& Jiménez-Araujo, A. (2009). Effect of extraction method on chemical composition and functional characteristics of high dietary fibre powders obtained from asparagus by-products. Food Chemistry, 113(2), 665-671. http://dx.doi.org/10.1016/j. foodchem.2008.07.075.

Ghani, U. (2015). Re-exploring promising a-glucosidase inhibitors for potential development into oral anti-diabetic drugs: finding needle in the haystack. European Journal of Medicinal Chemistry, 103, 133-162. http://dx.doi.org/10.1016/j.ejmech.2015.08.043. PMid:26344912.

Gomez, M. K., Singh, J., Acharya, P., Jayaprakasha, G. K., \& Patil, B. S. (2018). Identification and quantification of phytochemicals, antioxidant activity, and bile acid-binding capacity of garnet stem dandelion (Taraxacum officinale). Journal of Food Science, 83(6), 15691578. http://dx.doi.org/10.1111/1750-3841.14169. PMid:29802721.

González-Royo, E., Esteruelas, M., Kontoudakis, N., Fort, F., Canals, J. M., \& Zamora, F. (2017). The effect of supplementation with three 
commercial inactive dry yeasts on the colour, phenolic compounds, polysaccharides and astringency of a model wine solution and redwine. Journal of the Science of Food and Agriculture, 97(1), 172181. http://dx.doi.org/10.1002/jsfa.7706. PMid:26970323.

Huang, X., \& Nie, S. (2015). The structure of mushroom polysaccharides and their beneficial role in health. Food \& Function, 6(10), 32053217. http://dx.doi.org/10.1039/C5FO00678C. PMid:26345165.

Ilias, M., Naoufal, T., Maha, E. H., Aisha, A., Mourad, K., Rachid, A., Meryem, E. J., Yahia, C., Sherif, S. E., \& El Abbes, F. M. (2018). Pharmacological and chemical properties of some marine echinoderms. Revista Brasileira de Farmacognosia-Brazilian Journal of Pharmacognosy, 28(5), 575-581. http://dx.doi.org/10.1016/j. bjp.2018.05.015.

Isarawut, P., Korkiet, A., Khanita, K., Nagahiro, S., \& Siriporn, D. (2018). Production of reducing sugar from cassava starch waste (CSW) using solution plasma process (SPP). Carbohydrate Polymers, 205, 472-479. PMid:30446130.

Lavelli, V., Sri Harsha, P. S., Ferranti, P., Scarafoni, A., \& Iametti, S. (2016). Grape skin phenolics as inhibitors of mammalian $\alpha$-glucosidase and $\alpha$-amylase - effect of food matrix and processing on efficacy. Food \& Function, 7(3), 1655-1663. http://dx.doi.org/10.1039/C6FO00073H. PMid:26943361.

Liu, G. M., Sun, J., He, X. M., Tang, Y. Y., Li, J. M., Ling, D. N., Li, C., Li, L., Zheng, F., Sheng, J., Wei, P., \& Xin, M. (2018). Fermentation process optimization and chemical constituent analysis on longan (Dimocarpus Iongan, Lour.) wine. Food Chemistry, 256(1), 268-279. http://dx.doi.org/10.1016/j.foodchem.2018.02.064. PMid:29606448.

Lu, A., Yu, M., Meng Hong, S., Fang, Z., Xu, Y., Wang, S., Zhang, Y., Wang, W. (2018a). Antioxidant and anti-diabetic effects of Auriculaia auricula polysaccharides and their degradation by artificial gastrointestinal digestion - Bioactivity of $A$. auricula polysaccharides and their hydrolysates. Technologia alimentaria, 17(3), 277-288.

Lu, A., Yu, M., Shen, M., Xu, S., Xu, Z., Zhang, Y., Lin, Z., \& Wang, W. (2018b). Preparation of the A. auricula polysaccharides simulated hydrolysates and their hypoglycaemic effect. International Journal of Biological Macromolecules, 106, 1139-1145. http://dx.doi.org/10.1016/j. ijbiomac.2017.08.118. PMid:28847604.

Luyen, N. T., Dang, N. H., Binh, P. T. X., Hai, N. T., \& Dat, N. T. (2018). Hypoglycemic property of triterpenoid saponin PFS isolated from Polyscias fruticosa leaves. Anais da Academia Brasileira de Ciências, 90(3), 2881-2886. http://dx.doi.org/10.1590/0001-3765201820170945. PMid:30304222.

Ma, L. S., Chen, H. X., Zhu, W. C., \& Wang, Z. S. (2013). Effect of different drying methods on physicochemical properties and antioxidant activities of polysaccharides extracted from mushroom Inonotus obliquus. Food Research International, 50(2), 633-640. http://dx.doi. org/10.1016/j.foodres.2011.05.005.

Minbae, S., Sang, M., \& Haelee, Y. (2016). Extraction and Characterization of an Antihyperglycemic a-Glucosidase Inhibitor from Edible Mushroom, Pleurotus cornucopiae. Microbiology and Biotechnology Letters, 44(2), 124-129. http://dx.doi.org/10.4014/mbl.1602.02001.

Naumann, S., Schweiggert-Weisz, U., Bader-Mittermaier, S., Haller, D., \& Eisner, P. (2018). Differentiation of adsorptive and viscous effects of dietary fibres on bile acid release by means of in vitro digestion and dialysis. International Journal of Molecular Sciences, 19(8), 2193. http://dx.doi.org/10.3390/ijms19082193. PMid:30060480.
Oh, M. H., \& Yoon, K. Y. (2018). Comparison of the biological activity of crude polysaccharide fractions obtained from Cedrela sinensis using different extraction methods. Food Science \& Nutrition, 68, 327-334.

Reilly, M. P., \& Rader, D. J. (2003). The metabbolec syndrome: more than the sum of its parts. Circulation, 108(13), 1546-1551. http:// dx.doi.org/10.1161/01.CIR.0000088846.10655.E0. PMid:14517150.

Revenko, V. M., Lupanov, V. P., Lankin, V. Z., Tikhaze, A. K., Liakishev, A. A., \& Kukharchuk, V. V. (1991). Changes of blood antioxidative enzyme activity and lipid levels in patients with coronary atherosclerosis treated with probucol. Kardiologiia, 31(10), 41-44. PMid:1753580.

Reza, M. A., Hossain, M. A., Damte, D., Jo, W. S., Hsu, W. H., \& Park, S. C. (2015). Hypolipidemic and Hepatic Steatosis Preventing Activities of the Wood Ear Medicinal Mushroom Auriculaia auricula-judae (Higher Basidiomycetes) Ethanol Extract In Vivo and In Vitro. International Journal of Medicinal Mushrooms, 17(8), 723-734. http:// dx.doi.org/10.1615/IntJMedMushrooms.v17.i8.30. PMid:26559859.

Roşu, M., Timar, R., \& Păcuraru, S. (2000). Prevalence of serum lipid abnormalities in type 2 diabetes mellitus compared with normal adult population. Diabetes Research and Clinical Practice, 50(1), 320. http://dx.doi.org/10.1016/S0168-8227(00)81093-1.

Sudasinghe, H. P., \& Peiris, D. C. (2018). Hypoglycemic and hypolipidemic activity of aqueous leaf extract of Passiflora suberosa L. PeerJ, 6, e4389. http://dx.doi.org/10.7717/peerj.4389. PMid:29479498.

Sun, J., He, X. M., Zhao, M. M., Li, L., Li, C. B., \& Dong, Y. (2014). Antioxidant and nitrite-scavenging capacities of phenolic compounds from sugarcane (Saccharum officinarum L.) tops. Molecules, 19(9), 147160. http://dx.doi.org/10.3390/molecules190913147. PMid:25162956.

Sun, X., Liu, L., Ma, T., Yu, J., Huang, W., Fang, Y., \& Zhan, J. (2019). Effect of high $\mathrm{Cu}^{2+}$ stress on fermentation performance and copper biosorption of Saccharomyces cerevisiae during wine fermentation. Food Science and Technology (Campinas), 39(1), 19-26. http://dx.doi. org/10.1590/1678-457x.24217.

Tong, C., Zheng, Y., Guo, G., \& Wei, L. (2015). Hepatoprotective effect of a polysaccharide from Auriculaia auricula root on acute model of liver injury. Glycobiology, 25, 1287-1287.

Vinti Goel Ph, D. (1998). In vitro binding of bile salt to rhubarb stalk powder. Nutdim Research, 18(5), 893-903. http://dx.doi.org/10.1016/ S0271-5317(98)00074-8.

Zeng, X. Y., Li, Y. D., He, F., Chen, L. L., \& Lin, M. D. (1994). Pharmacological actions of hyphae body of A. auricula (L. ex Hook) underw and its alcoholic extract. Zhongguo Zhongyao Zazhi, 19(7), 430-432, 448. PMid:7802954.

Zhang, Y., Wang, Q., Tong, L., \& Zhong, G. (2016). Alkaline Extraction Optimization and Characterization of Auriculaia auricula Melanin. Shipin Kexue, 37(12), 27-32.

Zhu, K.-X., Nie, S.-P., Tan, L.-H., Li, C., Gong, D.-M., \& Xie, M.-Y. (2016) A Polysaccharide from Ganoderma atrum Improves Liver Function in Type 2 Diabetic Rats via Antioxidant Action and Short-Chain Fatty Acids Excretion. Agricultural and food chemistry, 64(9), 1938-1944.

Zieliński, H., Szawara-Nowak, D., Bączek, N., \& Wronkowska, M. (2019). Effect of liquid-state fermentation on the antioxidant and functional properties of raw and roasted buckwheat flours. Food Chemistry, 27, 291-297. http://dx.doi.org/10.1016/j.foodchem.2018.07.182. PMid:30236680. 